\title{
Evaluation of Material for Imitation Crab Leg by Prediction of Creep Behavior from Stress Relaxation Data
}

\author{
Teruo Nakayama, ${ }^{*}$ Satoshi Kanoh, ${ }^{*}$ and Eiji Niwa* \\ (Received September 7, 1987)
}

\begin{abstract}
The texture of the material for imitation crab leg in foreign and domestic markets was psychorheologically investigated and approached from both sides of stress relaxation and creep measurements. The values of the relaxation modulus $E(t)$ and the creep compliance $J(t)$ were calculated from a system of plots between stress and strain with time $t$ as a parameter. Then, continuous relaxation curves and continuous creep curves were drawn by the computer to give the best fit to the experimental points of $E(t)$ and $J(t)$. The connective equations between Maxwell model parameters of stress relaxation measurement and Voigt model parameters of creep measurement were derived from the differential equations. The Voigt rheological parameters were predicted from the stress relaxation data. Continuous creep curves were drawn using these predicted Voigt rheological parameters. For the most part, these curves fitted to the experimental points.

Agreement was observed between the sensory evaluation and the stress relaxation/creep measurement, while reasonable relation was not observed between the sensory evaluation and the plunger penetration test. The measurement of $\mathrm{E}(\mathrm{t})$ was also effective to evaluate the physical property of the materials for imitation crab leg in both foreign and domestic markets. And $E(t)$ and $\mathrm{J}(\mathrm{t})$ corresponded to the sensory softness even if the instrumental value of jelly strength did not correspond to the sense intensity of jelly strength.
\end{abstract}

Imitation crab leg (a kind of minced fish product) was developed in Japan, and the quality of this product is mainly related to its texture. The imitation crab legs of bound type and fiber type are familiar. The product of the latter type is an imitation of each genuine single fiber separated from a bundle of muscle fibers of genuine crab leg. This product is manufactured by cutting a large block of kamaboko (we call it the material) into fiber-like strings. In this study, we evaluated the material instead of imitation crab leg itself, because the texture of the latter depends on the texture of the former. It is the well-known fact among the manufactures that the requirements of suitable material for imitation crab leg are the strong sense intensity of jelly strength and the sensory softness. We elucidated previously that the sensory softness related to large values of creep compliance $J(t){ }^{1)}$ which are generally observed in easily deformable substances. In this study, the texture of the material for imitation crab leg in foreign and domestic markets is psychorheologically further investigated and approached from both sides of stress relaxation and creep measurements.

In our previous study, ${ }^{1)}$ we illustrated the be- havior of the material for imitation crab leg by six-element model. Isozaki et al..$^{21}$ illustrated the behavior of agar-agar gel also by six-element model. However, accurate determination of the numerical values of six elements is rather difficult, particularly in the range of short times. Therefore, it seems that in this sense, four elements are sufficient to represent the behavior of minced fish products. In addition, the aim of the present work is the prediction of creep behavior from stress relaxation data. The connective equations between Maxwell model parameters of stress relaxation measurement and Voigt model parameters of creep measurement are too complicated in six-element model. ${ }^{2)} \quad$ Therefore we are content with obtaining the parameter values of fourelement model in the aim of the present work.

\section{Materials and Methods}

\section{Minced Fish Products}

Four minced fish products were purchased from marine food companies. Ingredient compositions of these products were shown in Table 1.

Material for imitation crab leg in domestic market was produced by using excellent grade

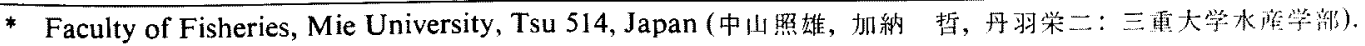


Table 1. Percentages of ingredients in four minced fish products

\begin{tabular}{|c|c|c|c|c|c|c|c|c|}
\hline \multirow{3}{*}{ Minced fish products } & \multicolumn{8}{|c|}{ Ingredients $(\%)$} \\
\hline & \multicolumn{3}{|c|}{ Minced fish } & \multirow[b]{2}{*}{ Wat 2} & \multirow[b]{2}{*}{ Starch } & \multirow[b]{2}{*}{ Salt } & \multirow[b]{2}{*}{ Sugar } & \multirow[b]{2}{*}{ Sorbit } \\
\hline & $\begin{array}{l}\text { Alaska } \\
\text { pollack }\end{array}$ & $\begin{array}{l}\text { Crimson } \\
\text { sea } \\
\text { bream }\end{array}$ & $\begin{array}{l}\text { Golden } \\
\text { thread }\end{array}$ & & & & & \\
\hline $\begin{array}{l}\text { Material for imitation } \\
\text { crab leg in domestic } \\
\text { market*2 }\end{array}$ & $49.7 * 1$ & 0.0 & 0.0 & 36.9 & 3.2 & 1.3 & 1.1 & 0.0 \\
\hline $\begin{array}{l}\text { Kamaboko } \\
\text { (high grade)*3 }\end{array}$ & $51.0^{* 1}$ & 3.9 & 3.9 & 26.5 & 3.1 & 1.5 & 2.0 & 0.0 \\
\hline $\begin{array}{l}\text { Material for imitation } \\
\text { crab leg in foreign } \\
\text { market*+ }\end{array}$ & $49.7 * 1$ & 0.0 & 0.0 & 36.3 & 6.9 & 1.5 & 1.1 & 1.0 \\
\hline $\begin{array}{l}\text { Kamaboko } \\
\text { (low grade)*5 }\end{array}$ & $47.5^{* 1}$ & 0.0 & 0.0 & 29.7 & 7.1 & 1.7 & 3.3 & 2.1 \\
\hline
\end{tabular}

*1 Excellent grade (the product of factory vessel).

*2 The other minor ingredients are egg white $4.8 \%$, flavoring sake $1.4 \%$, crab extract $0.8 \%$, seasoning $0.5 \%$, preservative $0.3 \%$.

*3 The other minor ingredients are egg white $2.9 \%$, flavoring sake $2.9 \%$, lizardfish extract $1.2 \%$, seasoning $0.8 \%$, phosphates $0.3 \%$.

*4 The other minor ingredients are seasoning $1.3 \%$, flavoring sake $1.1 \%$, crab extract $0.4 \%$, pigment $0.3 \%$, phosphates $0.2 \%$, crab flavor $0.1 \%$.

*5 The other minor ingredients are egg white $3.6 \%$, flavoring sake $2.1 \%$, soy protein $1.2 \%$, seasoning $1.2 \%$, phosphates $0.2 \%$, preservative $0.2 \%$.

minced Alaska pollack and adding a large amount of water. It was a block having $4.8 \mathrm{~cm}$ in thickness. It contained a small amount of starch. Steam heating was used in processing.

Kamaboko (high grade) was produced by using excellent grade minced Alaska pollack, minced crimson sea bream, and minced golden thread. It contained a small amount of starch. Steam heating was used in processing.

Material for imitation crab leg in foreign market was produced by using excellent grade minced Alaska pollack and adding a large amount of water. It was a block having $3.0 \mathrm{~cm}$ in thickness. It contained a large amount of starch. Steam heating was used in processing.

Kamaboko (low grade) was produced by using excellent grade minced Alaska pollack. It contained a large amount of starch. Steam heating was used in processing.

\section{Stress Relaxation and Creep Measurements}

A cubic sample having the edge length of 16.75 $\mathrm{mm}$ was cut off from each minced fish product by means of cutter blades set in parallel. Stress relaxation and creep behaviors were measured by Rheoner (RE 3305, Yamaden Co., Ltd.) at 19士 $1^{\circ} \mathrm{C}$. Constant strain or constant stress was applied to the sample from the same direction as the extruding direction during the manufacturing process. Original sample height was equal to the distance between top and bottom plates which

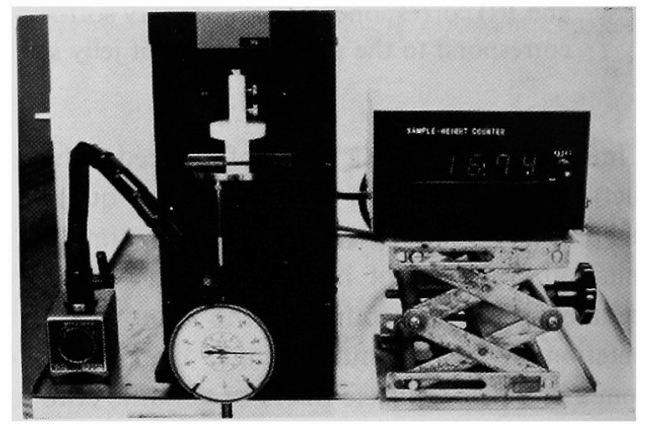

Fig. 1. Nakayama-Watanabe type Height Counter designed for stress relaxation and creep measurements. Inventors of this equipment are $\mathrm{T}$. Nakayama, Mie University and Y. Watanabe, Yamaden Co., Ltd.

just contacted and sandwiched the sample. Dial gauge (Fig. 1 left) was used for the direct measurement of the distance between top and bottom plates at an early stage of this study. NakayamaWatanabe type Height Counter (Fig. 1 right) was designed later for the electronical measurement of the distance between top and bottom plates.

Stress relaxation and creep measurements were carried out after the disappearance of the stress induced by the complete contact of the sample to the parallel plates. This stress was induced because the sample surface was slightly uneven. Details of above-mentioned procedure were written in our previous report. ${ }^{1)}$ Then the speed of sample table (bottom plate) was set at $5 \mathrm{~mm} / \mathrm{s}$ 
when a constant compression strain $(0.00,0.02$, $0.04,0.06,0.08,0.10$, or 0.12 ) was applied to the sample in the stress relaxation measurement. The sample table speed at $5 \mathrm{~mm} / \mathrm{s}$ was also selected when a constant compression stress $(0,6100$, $12200,18300,24400,30500$, or $\left.36600 \mathrm{dyn} / \mathrm{cm}^{2}\right)$ was applied to the sample in the creep measurement. The reason why a constant strain of 0.00 and a constant stress of 0 dyne $/ \mathrm{cm}^{2}$ were applied to the sample, was written in our previous report.1. Load sensor for $2 \mathrm{~kg}$ was used. The sensitivity voltage of $0.5 \mathrm{~V}$ and the chart speed of $2 \mathrm{~cm} / \mathrm{min}$ were selected.

\section{Computer Best-Fit Procedure}

The plot of observed values, the derivation of best-fit curve, and the graphics were done by the use of personal computer (PC 9801 VM, Nihon Electric Co., Ltd.).

\section{Sensory Evaluation and Plunger Penetration Test}

Sensory analysis of the texture of the sample was accomplished by a trained panel consisting of ten persons. Refer to the footnote $* 2$ of Table 5 . Sensory evaluation was done on the sense intensity of jelly strength and the softness. The former property was evaluated by the sense felt when a piece of the sample was bitten off, and the latter was evaluated by the sense felt when it was bitten softly. Sense intensity of jelly strength is a measure on the extent of firmness. Therefore a measure on the extent of softness is inversely related in size to the sense intensity of jelly strength. A three-point category scale of intensity was employed. In the evaluation of sense intensity of jelly strength, $+1=$ weak, $+2=$ medium, and $+3=$ strong. In the evaluation of softness, $-3=$ soft, $-2=$ medium, and $-1=$ hard. Intermediate (1/2 point) designations were also used if necessary.

Plunger penetration test was carried out on the jelly strength and the breaking deformation, ${ }^{3,4}$ by the use of Rheometer (NRM-2010J-CW, Fudoh Kogyo Co., Ltd.). Cubic samples having the edge length of $16.75 \mathrm{~mm}$ were used. The diameter of a ball-point plunger was $7 \mathrm{~mm}$, and the plunger penetration speed was $1 \mathrm{~mm} / \mathrm{s}$. Sample temperature was $19 \pm 1^{\circ} \mathrm{C}$. The sensory evaluation and the plunger penetration test were also done against the sample from the same direction as the extruding direction during the manufacturing process.

\section{Results and Discussion}

Texture of Material for Imitation Crab Leg Detected from Stress Relaxation and Creep Behaviors

From the relaxation data for different strains, we constructed a system of plots between stress $p$ and strain $e_{0}$ with time $t$ as parameter. ${ }^{5)}$ The plots thus obtained were linear (maximum strain 0.12 ), and their inclinations to the $\mathrm{e}_{0}$ axis gave the values of the relaxation modulus $E(t)$. The straight lines drawn to give the best fit to the experimental points did not pass through the origin of coordinates. The reason is written in our previous report. ${ }^{13}$

From the creep data for different stresses, we also constructed a system of plots between strain e and stress $p_{0}$ with time $t$ as parameter. ${ }^{1)}$ The plots thus obtained were linear in the range of small stresses, and their inclinations to the $p_{0}$ axis gave the values of the creep compliance $J(t)$. The straight lines drawn to give the best fit to the ex-

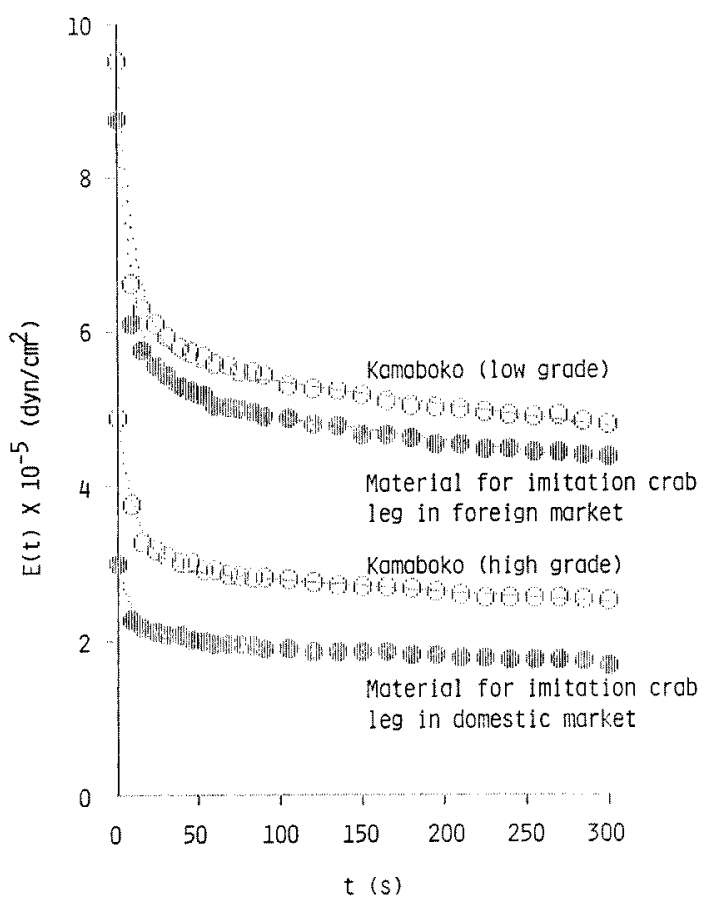

Fig. 2. Relaxation behavior of the minced fish products.

t: time

$E(t)$ : relaxation modulus

Points are experimental values, while continuous curves are drawn by the computer best-fit procedure with the four-element model. 


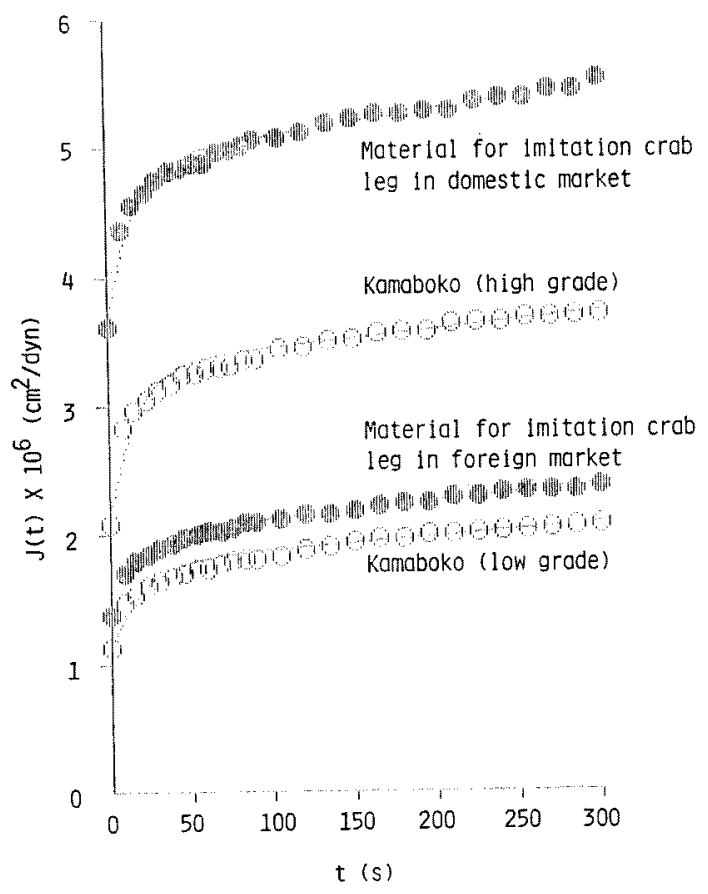

Fig. 3. Creep behavior of the minced fish products. $t$ : time

$\mathrm{J}(\mathrm{t})$ : creep compliance

Points are experimental values, while continuous curves are drawn by the computer best-fit procedure with the four-element model.

perimental points did not also pass through the origin of coordinates. The similar tendency was reported in our previous study. ${ }^{13}$

In Figs. 2 and 3, the relaxation modulus $E(t)$ and creep compliance $J(t)$ of minced fish products were shown, respectively. Solid circle $(\bullet)$ was used for two types of the material for imitation crab leg, while open circle $(O)$ was used for two types of kamaboko.

The change of relaxation modulus $E(t)$ with time $t$ was expressed as:

$$
E(t)=E_{M 1} e^{-t / \tau} \tau_{M 1}+E_{M 2} e^{-t / t_{M 2}}
$$

where $E_{M 1}$ and $\tau_{M 1}$ denote the elasticity of the spring, and the relaxation time, of the ith Maxwell element, respectively $(i=1,2)$. The relaxation time is defined by the following relation:

$$
\tau_{M 1}=\frac{\eta_{M 1}}{E_{M 1}}
$$

where $\eta_{M 1}$ denote the viscosity of the dash-pot of the ith Maxwell element.

The change of creep compliance $J(t)$ with time $t$ was expressed as:

$$
J(t)=\frac{1}{E_{V 1}}+\frac{1}{E_{v 2}}\left(1-e^{-t / \tau} v 2\right)+\frac{1}{\eta_{v 3}} t
$$

where $E_{\nabla_{1}}$ and $\tau_{\nabla 1}$ denote the elasticity of the spring, and the retardation time, ${ }^{*}$ of the ith Voigt element, respectively $(i=1,2)$. The retardation time is defined by the following relation:

$$
\tau_{\nabla 1}=\frac{\eta_{\nabla 1}}{E_{\nabla 1}}
$$

where $r_{\nabla 1}$ denote the viscosity of the dash-pot of the ith Voigt element.

In Figs. 2 and 3, continuous relaxation curves and continuous creep curves were drawn by the computer to give the best fit to the experimental points using Eqs. (1) and (3), respectively.

The value of $E(t)$ was small at any time $t$ in material for imitation crab leg in domestic market (Fig. 2). It was medium at any time in kamaboko (high grade), and large in both material for imitation crab leg in foreign market and kamaboko (low grade). Maxwellian rheological parameters calculated by the computer best-fit procedure are listed in Table 2. Though four minced fish products had similar relaxation times $\tau_{M 1}$ and $\tau_{M 2}$ (1600-1700 s and 10-11 s), the other parameters $\left(E_{M 1}, \eta_{M 1}, E_{M 2}\right.$, and $\left.\eta_{M 2}\right)$ were small in material for imitation crab leg in domestic market, medium in kamaboko (high grade), and large in both material for imitation crab leg in foreign market and kamaboko (low grade). The latter two products were distinguished by the fact that the viscosity $\eta_{M 1}$ of material for imitation crab leg in foreign market was clearly smaller than that of kamaboko (low grade).

The value of $J(t)$ was large at any time $t$ in material for imitation crab leg in domestic market (Fig. 3). It was medium at any time in kamaboko (high grade), and small in both material for imitation crab leg in foreign market and kamaboko (low grade). Voigt rheological parameters calculated by the computer best-fit procedure are listed in Table 3. Though four minced fish products had a similar retardation time $\tau_{\mathrm{v} 2}(14-19 \mathrm{~s})$, the elasticity $E_{\mathrm{v}_{2}}$ and the viscosity $\eta_{\mathrm{v} 2}$ were small

* Generally $\tau_{\mathrm{K}}$ is used for the retardation time, named after Kelvin model (1875). Voigt presented the same model (1890) during his research course concerning the creep phenomenon. Nowadays, the technical term "Voigt model" is more often used to express this phenomenon. In this report, several complicated equations are presented. Therefore to assure the simplicity, we used $\tau_{\mathrm{V}}$ instead of $\tau_{\mathrm{K}}$ for the retardation time. 
Table 2. Maxwellian rheological parameters calculated by the computer best-fit procedure from relaxation modulus time responses

\begin{tabular}{|c|c|c|c|c|c|c|}
\hline Minced fish products & $\begin{array}{c}\mathrm{E}_{\mathrm{M1}} \times 10^{-5} \\
\left(\mathrm{dyn} / \mathrm{cm}^{2}\right)\end{array}$ & $\begin{array}{c}\eta_{\mathrm{M} 1} \times 10^{-5} \\
\text { (poise) }\end{array}$ & $\begin{array}{l}\tau_{M 1} \\
\text { (s) }\end{array}$ & $\begin{array}{c}\mathrm{E}_{\mathrm{M} 2} \times 10^{-5} \\
\left(\mathrm{dyn} / \mathrm{cm}^{2}\right)\end{array}$ & $\begin{array}{c}\eta_{\mathrm{M} 2} \times 10^{-3} \\
\text { (poise) }\end{array}$ & $\begin{array}{l}\tau_{\mathrm{M}} \\
\text { (s) }\end{array}$ \\
\hline $\begin{array}{l}\text { Material for imitation } \\
\text { crab leg in domestic } \\
\text { market }\end{array}$ & 2.0 & 3500 & 1700 & 0.9 & 10 & 10 \\
\hline Kamaboko (high grade) & 2.9 & 5200 & 1700 & 1.9 & 21 & 11 \\
\hline $\begin{array}{l}\text { Material for imitation } \\
\text { crab leg in foreign } \\
\text { market }\end{array}$ & 5.1 & 8400 & 1600 & 3.5 & 38 & 10 \\
\hline Kamaboko (low grade) & 5.6 & 9800 & 1700 & 3.8 & 43 & 11 \\
\hline
\end{tabular}

The experimental error of stress relaxation curves was within $6.0 \%$ at the applied strain of 0.00 , within $4.9 \%$ at the strain of 0.02 , within $2.6 \%$ at the strain of 0.04 , within $2.2 \%$ at the strain of 0.06 , within $3.9 \%$ at the strain of 0.08 , within $4.4 \%$ at the strain of 0.10 , and within $3.8 \%$ at the strain of 0.12 . Above rheological parameters were calculated by incorporating all these stress relaxation curves as the input memory and averaging them in the form of relaxation modulus.

Table 3. Voigt rheological parameters calculated by the computer best-fit procedure from creep compliance time responses

\begin{tabular}{|c|c|c|c|c|c|}
\hline Minced fish products & $\begin{array}{l}E_{Y 1} \times 10^{-5} \\
\left(\mathrm{dyn}^{-5} \mathrm{~cm}^{2}\right)\end{array}$ & $\begin{array}{r}\mathrm{E}_{\mathrm{V} 2} \times 10^{-5} \\
\left(\mathrm{dyn} / \mathrm{cm}^{2}\right)\end{array}$ & $\begin{array}{c}\eta \mathrm{vg} \times 10^{-5} \\
\quad \text { (poise) }\end{array}$ & $\begin{array}{l}\tau \mathrm{vg} \\
(\mathrm{s})\end{array}$ & $\begin{array}{c}\eta_{v 3} \times 10^{-5} \\
\text { (poise) }\end{array}$ \\
\hline $\begin{array}{l}\text { Material for imitation } \\
\text { crab leg in domestic } \\
\text { market }\end{array}$ & 2.7 & 7.8 & 110 & 14 & 4900 \\
\hline Kamaboko (high grade) & 4.7 & 8.1 & 120 & 15 & 7200 \\
\hline $\begin{array}{l}\text { Material for imitation } \\
\text { crab leg in foreign } \\
\text { market }\end{array}$ & 7.2 & 16.3 & 280 & 17 & 7500 \\
\hline Kamaboko (low grade) & 8.8 & 15.0 & 280 & 19 & 10000 \\
\hline
\end{tabular}

The experimental error of creep curves was within $10.0 \%$ at the applied stress of $0 \mathrm{dyn} / \mathrm{cm}^{2}$, within $6.3 \%$ at the stress of 6100 dyn $/ \mathrm{cm}^{2}$, within $2.8 \%$ at the stress of $12200 \mathrm{dyn} / \mathrm{cm}^{2}$, within $2.2 \%$ at the stress of $18300 \mathrm{dyn} / \mathrm{cm}^{2}$, within $2.8 \%$ at the stress of 24400 dyn $/ \mathrm{cm}^{2}$, within $6.9 \%$ at the stress of $30500 \mathrm{dyn} / \mathrm{cm}^{2}$, within $4.6 \%$ at the stress of $36600 \mathrm{dyn} / \mathrm{cm}^{2}$. Above rheological parameters were calculated by incorporating all these creep curves as the input memory and averaging them in the form of creep compliance.

in both material for imitation crab leg in domestic market and kamaboko (high grade), and large in both material for imitation crab leg in foreign market and kamaboko (low grade). The elasticity $E_{\mathrm{V} 1}$ was small in material for imitation crab leg in domestic market, medium in kamaboko (high grade), and large in both material for imitation crab leg in foreign market and kamaboko (low grade). The viscosity $\eta_{\nabla 3}$ was small in material for imitation crab leg in domestic market, medium in both kamaboko (high grade) and material for imitation crab leg in foreign market, and large in kamaboko (low grade). In the comparison between material for imitation crab leg in foreign market and kamaboko (low grade), the viscosity $\eta_{73}$ was clearly smaller in the former product than in the latter.

In the next step, two types of four-element model are shown in Fig. 4 with the notation for each element. On both the generalized Voigt model and the generalized Maxwell model, differential equations were made to express the rela-

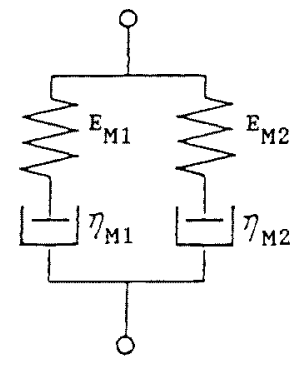

Maxwell type

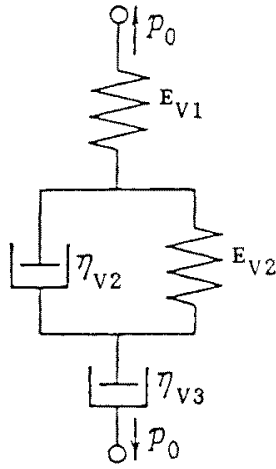

Voigt type
Fig. 4. Two types of four-element model.

tion between stress and strain. Since the coefficients of same power term were equal in these equations, the following relations:

$$
\begin{aligned}
& E_{\nabla 1}=E_{M 1}+E_{M 2} \\
& E_{\nabla 2}=\frac{E_{M 1} E_{M 2}\left(E_{M 1}+E_{M 2}\right)\left(\eta_{M 1}+\eta_{M 2}\right)^{2}}{\left(E_{M 1} \eta_{M 2}-E_{M 2} \eta_{M 1}\right)^{2}}
\end{aligned}
$$


Table 4. Voigt rheological parameters predicted from relaxation modulus time responses

\begin{tabular}{lccccc}
\hline \multicolumn{1}{c}{ Minced fish products } & $\begin{array}{c}\mathrm{E}_{\mathrm{V} 1} \times 10^{-5} \\
\left(\mathrm{dyn} / \mathrm{cm}^{2}\right)\end{array}$ & $\begin{array}{c}\mathrm{E}_{\mathrm{V} 2} \times 10^{-5} \\
\left(\mathrm{dyn} / \mathrm{cm}^{2}\right)\end{array}$ & $\begin{array}{c}\eta_{\mathrm{V}_{2}} \times 10^{-5} \\
(\text { poise })\end{array}$ & $\begin{array}{c}\tau_{\mathrm{V} 2} \\
(\mathrm{~s})\end{array}$ & $\begin{array}{c}\eta_{\mathrm{V} 3} \times 10^{-5} \\
\text { (poise) }\end{array}$ \\
\hline $\begin{array}{l}\text { Material for imitation } \\
\text { crab leg in domestic }\end{array}$ & 2.9 & 6.3 & 100 & 16 & 3500 \\
market & & & & & \\
Kamaboko (high grade) & 4.8 & 7.6 & 140 & 18 & 5200 \\
$\begin{array}{l}\text { Material for imitation } \\
\text { crab leg in foreign }\end{array}$ & 8.7 & 13.0 & 230 & 17 & 8500 \\
market & & & & & \\
Kamaboko (low grade) & 9.5 & 14.2 & 260 & 18 & 9900 \\
\hline
\end{tabular}

The experimental error of stress relaxation curves is written in the footnote of Table 2 .

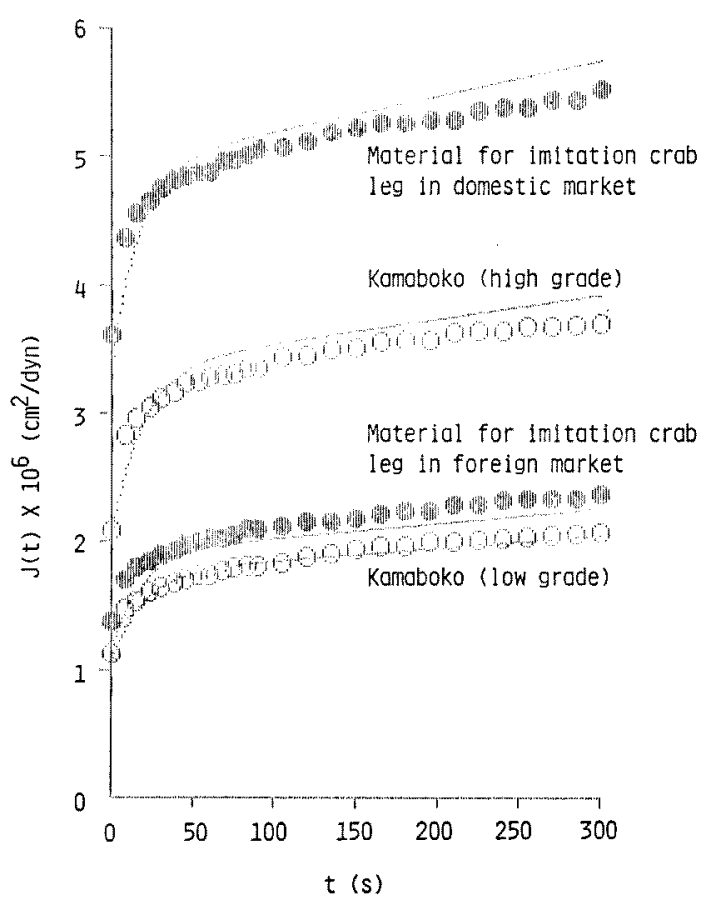

Fig. 5. Predicted creep behavior of the minced fish products. The prediction was made from relaxation modulus time responses.

t: time

$\mathrm{J}(\mathrm{t})$ : creep compliance

Points are experimental values, while continuous curves are predicted with the four-element model, from relaxation modulus time responses.

$$
\begin{aligned}
& \eta_{\mathrm{V} 2}=\frac{\eta_{\mathrm{M} 1} \eta_{\mathrm{M} 2}\left(\eta_{\mathrm{M} 1}+\eta_{\mathrm{M} 2}\right)\left(\mathrm{E}_{\mathrm{M} 1}+\mathrm{E}_{\mathrm{M} 2}\right)^{2}}{\left(\mathrm{E}_{\mathrm{M} 1} \eta_{\mathrm{M} 2}-\mathrm{E}_{\mathrm{M} 2} \eta_{\mathrm{M} 1}\right)^{2}} \\
& \eta_{\mathrm{V} 3}=\eta_{\mathrm{M} 1}+\eta_{\mathrm{M} 2}
\end{aligned}
$$

were derived. To use these relations and substitute Maxwellian rheological parameters calculated from relaxation modulus time responses, for $\mathrm{E}_{\mathrm{M} 1}, \eta_{M 1}, \mathrm{E}_{\mathrm{M} 2}, \eta_{\mathrm{M}}$, Voigt rheological parameters were predicted.

In Fig. 5, continuous creep curves were drawn using these predicted Voigt rheological parameters. For the most part, these curves fitted to the experimental points. In Table 4, these rheological parameters are listed. The elasticity $E_{v_{1}}$ was small in material for imitation crab leg in domestic market, medium in kamaboko (high grade), and large in both material for imitation crab leg in foreign market and kamaboko (low grade) (Table 4). These tendencies were the same as those discussed in creep compliance time responses (Table 3). Though four minced fish products had a similar retardation time $\tau_{\mathrm{v} 2}(16-18 \mathrm{~s}$ ) (Table 4), the elasticity $E_{\nabla 2}$ and the viscosity $\eta_{\nabla 2}$ were small in both material for imitation crab leg in domestic market and kamaboko (high grade), and large in both material for imitation crab leg in foreign market and kamoboko (low grade). These tendencies were also the same as those discussed in creep compliance time responses (Table 3). The viscosity $\eta_{\nabla s}$ (Table 4) was small in both material for imitation crab leg in domestic market and kamaboko (high grade), and large in both material for imitation crab leg in foreign market and kamaboko (low grade). These tendencies were similar to those discussed in creep compliance time responses (Table 3), but somewhat different in the comparison between kamaboko (high grade) and material for imitation crab leg in foreign market. In the comparison between material for imitation crab leg in foreign market and kamaboko (low grade) (Table 4), the viscosity $\eta_{\nabla 3}$ was also clearly smaller in the former product than in the latter. This tendency was the same as that discussed in creep compliance time responses (Table 3).

For the most part, Voigt parameters predicted from relaxation modulus time responses were in good agreement with Voigt parameters calculated from creep compliance time responses. 
Table 5. Sensory evaluation and plunger penetration test of minced fish products

\begin{tabular}{|c|c|c|c|c|}
\hline \multirow{2}{*}{ Minced fish products } & \multicolumn{2}{|c|}{ Sensory evaluation } & \multicolumn{2}{|c|}{ Plunger penetration test } \\
\hline & $\begin{array}{l}\text { Sense intensity } \\
\text { of jelly } \\
\text { strength }\end{array}$ & Softness ${ }^{* 1}$ & $\begin{array}{l}\text { Jelly strength } \\
\text { (g) }\end{array}$ & $\begin{array}{l}\text { Breaking } \\
\text { deformation } \\
\quad(\mathrm{mm})\end{array}$ \\
\hline $\begin{array}{l}\text { Material for imitation } \\
\text { crab leg in domestic } \\
\text { market }\end{array}$ & $+3.00 \pm 0.00^{*}$ & $-3.00 \pm 0.00^{* 2}$ & $653 \pm 66^{* 2}$ & $13.3 \pm 0.5^{* 2}$ \\
\hline Kamaboko (high grade) & $+2.55 \pm 0.26$ & $-2.50 \pm 0.22$ & $935 \pm 35$ & $14.5 \pm 0.1$ \\
\hline $\begin{array}{l}\text { Material for imitation } \\
\text { crab leg in foreign } \\
\text { market }\end{array}$ & $+1.50 \pm 0.22$ & $-1.00 \pm 0.00$ & $652 \pm 26$ & $11.8 \pm 0.2$ \\
\hline Kamaboko (low grade) & $+1.00 \pm 0.00$ & $-1.00 \pm 0.00$ & $716 \pm 14$ & $12.2 \pm 0.3$ \\
\hline
\end{tabular}

Psychorheological Discussion of the Texture of Material for Imitation Crab Leg

The value of $E(t)$ was small at any time in material for imitation crab leg in domestic market. It was medium at any time in kamaboko (high grade), and large in both material for imitation crab leg in foreign market and kamaboko (low grade) (Fig. 2).

The value of $J(t)$ was large at any time in material for imitation crab leg in domestic market. It was medium at any time in kamaboko (high grade), and small in both material for imitation crab leg in foreign market and kamaboko (low grade) (Fig. 3).

In other words, material for imitation crab leg in domestic market needed small stress for small deformation, and deformed easily under small stress. Kamaboko (high grade) needed medium stress for small deformation, and deformed moderately under small stress. Both material for imitation crab leg in foreign market and kamaboko (low grade) needed large stress for small deformation, and deformed with difficulty under small stress.

Material for imitation crab leg in domestic market acquired the highest scores in both the sense intensity of jelly strength and the sensory softness (Table 5). Kamaboko (high grade) acquired high scores in these categories. Both material for imitation crab leg in foreign market and kamaboko (low grade) acquired low scores in those categories.

In plunger penetration test, materials for imitation crab leg in both domestic and foreign markets and kamaboko (low grade) had the jelly strength of similar values (Table 5). Kamaboko (high grade) only had the jelly strength of large values. In the breaking deformation (Table 5), kamaboko (high grade) also had large values, material for imitation crab leg in domestic market had medium values, and both material for imitation crab leg in foreign market and kamaboko (low grade) had small values.

From the above-mentioned results, we conclude that good agreement was observed between the sensory evaluation (i.e. the sense intensity of jelly strength, the sensory softness) and the stress relaxation/creep measurement (i.e. $E(t), J(t))$, while reasonable relation was not observed between the sensory evaluation and the plunger penetration test (i.e. the jelly strength, the breaking deformation).

Shimizu and Simidu ${ }^{\theta)}$ mentioned that in the sensory evaluation of "ashi" of kamaboko, the categories of the sense intensity of jelly strength and the sensory softness are included. "Ashi" of kamaboko has been instrumentally evaluated very often by jelly strength (the resistant stress at the breaking point). ${ }^{7}{ }^{8}$ " "Ashi" is a composite property also evaluated as the elasticity at the small strain, ${ }^{\text {g) }}$ the breaking deformation, ${ }^{8)}$ etc. The large drop of force after the first peak of the force vs. deformation curve, related to "ashi" when plunger penetration test was carried out on minced sardine products. ${ }^{10,11)}$ In our previous study, ${ }^{1}$ $J(t)$ related to the sensory softness. In this study, $E(t)$ also related to the sensory softness. Therefore both $E(t)$ and $J(t)$ would relate to the result of the sensory evaluation of "ashi". In this study, $J(t)$ was derived from $E(t)$ theoretically, and this prediction of $J(t)$ from the data of $E(t)$ was proved to be substantial experimentally. Finally 
we conclude that the measurement of $\mathrm{E}(\mathrm{t})$ was also effective to evaluate the physical property of minced fish products (e.g. the materials for imitation crab leg in both domestic and foreign markets). It can be converted to $\mathrm{J}(\mathrm{t})$ theoretically. And these functions $E(t)$ and $J(t)$ corresponded to the sensory softness even if the instrumental value of jelly strength did not correspond to the sense intensity of jelly strength.

\section{References}

1) T. Nakayama, K. Hatae, Y. Matsui, S. Kanoh, and E. Niwa: Nippon Suisan Gakkaishi, 53, 2031-2039 (1987).

2) H. Isozaki, H. Akabane, and N. Nakahama: Nippon Nogeikagaku Kaishi, 50, 265-272 (1976).

3) H. Aoki, A. Mochizuki, and H. Tsuyuki: Nippon
Shokuhin Kogyo Gakkaishi, 29, 180-184 (1982).

4) E. Niwa, T. Konagaya, and M. Miyake: Nippon Nogeikagaku Kaishi, 46, 295-301 (1972).

5) H. Fujita and K. Ninomiya: Bull. Chem. Soc. Japan, 26, 24-29 (1953).

6) Y. Shimizu and W. Simidu: Nippon Suisan Gakkaishi, 19, 596-602 (1953).

7) M. Miyake, Y. Horiguchi, and K. Hayashi: Nippon Suisan Gakkaishi, 21, 1241-1243 (1956).

8) M. Okada: Bull. Tokai Reg. Fish. Res., No. 36, 21-126 (1963).

9) J. Matsumoto and T. Arai: Nippon Suisan Gakkaishi, 17, 9-16 (1952).

10) T. Nakayama, T. Ichikawa, S. Kanoh, and E. Niwa: Nippon Suisan Gakkaishi, 53, 20212030 (1987).

11) T. Nakayama, Y. Kashiwagi, S. Kanoh, and E. Niwa: Nippon Suisan Gakkaishi, 54, 123-128 (1988). 